\title{
Local innovation systems in Poland - the beginning of the road
}

\begin{abstract}
Local innovation systems (LIS) constitute a relatively new term as usually the discussion about the systemic approach to innovation has focused on the level of countries, and most of all - regions. In this article an attempt was made to assess Polish municipalities from the perspective of their potential for development of local innovative systems. The performed factor analysis allowed characterization of five types of institution networks which may impact creation and development of LIS. The study was completed with case studies in selected voivodeship cities as centres of the highest concentration of institutions usually building local innovation systems, three of which were capitals of the poorest regions in Poland.
\end{abstract}

\section{Keywords}

Local innovation system • local development • innovation • institutions • less developed regions $\cdot$ regional innovation strategies

(C) University of Warsaw - Faculty of Geography and Regional Studies
Wojciech Dziemianowicz', Agnieszka Laskowska ${ }^{2}$ Klaudia Peszat ${ }^{3}$

'Department of Local Development and Policy, Faculty of Geography and Regional Studies, University of Warsaw, Poland

e-mail:w.dziemianowicz@uw.edu.pl

2Department of Local Development and Policy, Faculty of Geography and Regional Studies, University of Warsaw, Poland e-mail: agnieszkalaskowska@hotmail.com

${ }^{3}$ Department of Local Development and Policy, Faculty of Geography and Regional Studies, University of Warsaw, Poland e-mail: k.peszat@uw.edu.pl

Received: 2 February 2017 Accepted: 5 June 2017

\section{Introduction}

For at least three decades the subject of innovation has not only been taken up by theoreticians, but has also become the subject (sometimes the core subject) of various public policies. In recent years, increasing attention has been paid to matters of territorialisation of the actions that have been undertaken (OECD 2009; Pylak 2015; Zaucha et al., 2015) and to urban matters, in particular to metropolitan areas, within development policies. In metropolitan areas, dynamic development processes occur that result from the many different interactions between the people and institutions who create metropolitan areas (Dicken 2007). Therefore, without a doubt, large cities can be the first to draw attention to themselves when discussion about the possibilities of innovation development is taken from the national and regional level to a lower level. Do only metropolitan areas have the features, opportunities and possibilities for creating local innovation systems? This article tries to answer this question from the perspective of local units in Poland. The study was conducted based on surveys given to representatives of local authorities (528 people, which constitutes $21 \%$ of the entire population). ${ }^{1} \mathrm{We}$ also used information from the structured in-depth interviews that were implemented within studies on the development paths of less developed regions.

${ }^{1}$ The study was conducted based on statistical data from the Central Statistical Office of Poland, SIMIK and surveys from the research "Development factors affecting Polish communes in the context of the economic crisis and the new challenges of the European Union". The surveys used in the research were sent by e-mail to 2,500 municipalities in Poland in June 2015. Representatives of local authorities from 528 municipalities returned the survey, which constitutes $21 \%$ of the entire population.
Between National and Local Innovation Systems

A review of the literature on the subject allows at least several conclusions to be formulated that lead to the legitimacy of studying local innovation systems. The first conclusion concerns the evolution of a systemic approach to innovation in a territorial context. Tödtling and Kaufmann (1999), while analysing innovation systems in European regions, paid attention to the fact that the systemic approach involves multi-layer relations; they listed regional, national and supranational levels. Asheim, Smith and Oughton (2011), in reviewing the theories related to innovation systems, additionally indicated the global innovation system, while Frenkel and Maital (2014) focused their attention on local systems (com. Mayer et al., 2016). It is worth paying attention to the fact that the multi-layer specificity causes a problem in determining the boundary between what is regional and what is a local system.

Global, supranational, national, regional and local innovation systems suit the previously outlined concepts, but they also meet the idea of an economy based on knowledge with which the attempts to stimulate innovation using various public policies are consistent (Charles et al., 2000, Wojnicka-Sycz \& Sycz 2016). Territorial innovation systems refer to concepts such as, innovative milieu (Camagni 1995), innovative clusters (Porter 1990), industrial districts (Capello 1999), and learning regions (Moulaert \& Sekia 2003), among others. Also, relatively new concepts, such as intelligent specializations have become areas of interest for the systemic approach (Dziemianowicz \& Peszat 2014; Foray 2015).

In each of the systemic approaches, it is important which institutions create the system and what kind of relationships occur 
between those institutions (Tödtling \& Trippl 2011). In determining which entities create (and should create) the territorial innovation system, one could use the quadruple helix idea (Leydesdorff 2012). In reference to this idea, it is first of all necessary to list companies as particular economic entities, in which the processes for creating innovation take place, motivated by, among other things, the improvement of the product being offered and the growth in efficiency or competitiveness of a given enterprise (Sikora \& Uziębło 2013). In the context described, companies should be considered as a network of co-operators and competitors (related to, for example, value chains - Porter 1998). Another group is created by what is broadly understood to be the field of science (educational institutions, research institutions, technological parks) whose task it is to provide knowledge and facilitate its exchange (Diez 2000). The third group is administration, which creates law, determines the conditions of the development of innovation and other administrative organizations, and whose task it is to implement policies (e.g. labour offices) (Carrincazeaux $\&$ Gaschet 2015). Some researchers also pay attention to national, regional and local development agencies (Moodysson \& Zukauskaite 2014). The fourth group is society; in the innovation system various features characterizing a given society are important (Florida 2002).

The basic values around which innovation systems are created and that are transferred between system participants are, knowledge and innovations (Asheim 2007). In the literature on the subject, there are two basic types of knowledge: explicit (formal), and hidden (tacit), which is characterized by a high degree of individualisation and formalization that makes it more difficult to grasp, but it is still important for the development of an organization. For innovation system development, knowledge transfer processes (Fischer 2001) and innovation diffusion processes obviously play a key role. Regardless of the diversity of terms applied by researchers concerning these two matters (see Dapbrowska 2015), it should be assumed that the exchange and distribution of knowledge between various entities positively impacts the possibility of generating innovation. The theory of the spatial diffusion of innovation, which has been developed since the 1960s proves that the process of distributing and promoting innovation occurs in geographic space (however, this is usually a long-term process) (Hägerstrand 1967, after: Dąbrowska 2015). The concept of learning regions has been developed since the 1990s (Florida 1995; Perry 2010). It is known that skills and knowledge are not acquired "once and for all", and to win or equal the competition they must be continuously developed. In a learning region in which strong relations occur between the various groups of actors and the transfer and exchange of knowledge are common, there are greater possibilities for adapting to changing conditions as well as being included in globalization.

To sum up this part of literature review, it can be assumed that systems composed of numerous institutions, and rich relations between these institutions, should most often characterize metropolises and large cities (Capello 2012; Geenhuizen \& Ye 2015). But if we take into account the key objective of such systems, that is, the creation and practical application of various types of knowledge, not necessarily innovation; it turns out that various knowledge networks also exist in small municipalities, including rural communities (Brunow \& Miersch 2015). It is probable that these networks, due to their institutional constraints, must maintain strong relationships with their surroundings, which may prompt them to treat them as subsystems of larger organizational networks.

\section{Typologies of innovation systems}

The broad literature on the subject allows for various attempts at typology to be indicated for territorial innovation systems. For instance, Asheim and Isaksen (2002) differentiated three types of regional innovation systems: (1) territorially embedded regional innovation networks; (2) regional networked innovation systems; and (3) regionalised national innovation systems. This typology shows a dependency between the various levels of spatial organization, but it also draws attention to the difference between what is locally embedded and what is regional. According to the authors, in the case of a territorially embedded regional innovation network, the organizations responsible for innovation are situated locally, but there are only a few of them, in contrast to the second type based on the network cooperation of knowledge institutions. The first type bases its development on geographic, social and cultural proximity, while the second type is a planned and systematic cooperation network. In both types knowledge transfer takes place based on interaction; while the third type, the regionalised national innovation system, is based on linear knowledge transfer from institutions usually situated outside a given region. The basis of such a system is to transfer knowledge and good practices into a given region.

While, Frenkel and Maital (2014), while analysing the situation in developing countries, distinguish three types of local innovation systems: (1) those driven by governments; (2) those driven by companies; and (3) those driven by universities. The first type depends on government policy, the purpose of which is to attract knowledge and technology to a country. In this context, high expectations are held of foreign companies. While, the type of local innovation systems depends on companies, it is characterized by the significant role played by large enterprises who generate knowledge, and have access to technology and broad international relations. Small and medium enterprises focus rather on production; therefore, they require the support of national, regional and local institutions. Local innovation systems, driven by universities, involve these units not only in the education process and delivering well-educated graduates to the market. Most of all, an active role in creating spin-off and start-up enterprises is important ${ }^{2}$ in building university-business relations (a so-called entrepreneurial university; see Foss \& Gibson 2015) and in still conducting research.

Activity of institutions in the local development process according to local authorities

In the study conducted, 17 different types of institutions were indicated, whose activities were assessed by the representatives of local authorities. ${ }^{3}$ As a result of the factor analysis conducted, five dimensions were obtained, which together explain more than $67 \%$ of the variations (Table 1 ).

The differences between the sizes of the variances across particular dimensions are small, except for the last dimension, which characterizes regional development institutions at the voivodeship level. This means that the country is equipped with a variety of institutions, which can be a factor in development. The largest portion of the variance is explained by the innovator's dimension, which consists of entities creating knowledge, and who are responsible for education and knowledge transfer. Therefore, the dimension most discussed is presented in voivodeship cities and former voivodeship capitals, but not only these (Figure 1). Our study included 79 cities (urban municipalities), of which almost $50 \%$ are characterized by a highly developed "innovators"

\footnotetext{
${ }^{2}$ Attention was also paid to this aspect in EU documents: the European Commission 2003.

${ }^{3}$ Only institutions indicated by local authorities in the surveys as being active and important for local development were used in the factor analysis. The surveys used in this study were conducted as a part of the research "Development factors affecting Polish communes in the context of the economic crisis and the new challenges of the European Union", and were sent by e-mail to 2,500 municipalities in Poland in June 2015. Representatives of local authorities from 528 municipalities returned the survey, which constitutes $21 \%$ of the entire population.
} 
MISCELLANEA GEOGRAPHICA - REGIONAL STUDIES ON DEVELOPMENT

Vol. $21 \cdot$ No. $2 \cdot 2017$ • pp. 60-67 • ISSN: 2084-6118 • DOI: 10.1515/mgrsd-2017-0024

Table 1. Results of factor analysis

\begin{tabular}{|c|c|c|c|c|c|}
\hline \multirow[b]{2}{*}{ Institution type } & \multicolumn{5}{|c|}{ Dimensions of institutional networks } \\
\hline & innovators & entrepreneurs & $\begin{array}{c}\text { local } \\
\text { development } \\
\text { agencies }\end{array}$ & $\begin{array}{c}\text { economic } \\
\text { self- } \\
\text { government }\end{array}$ & $\begin{array}{c}\text { regional } \\
\text { development } \\
\text { agencies }\end{array}$ \\
\hline universities & .815 & & & & \\
\hline secondary schools & .759 & & & & \\
\hline private consulting firms & .682 & & & & \\
\hline R\&D institutions & .637 & & & & \\
\hline special economic zones & .471 & & & & \\
\hline $\begin{array}{c}\text { groups of entrepreneurs in neighbouring } \\
\text { municipalities }\end{array}$ & & .804 & & & \\
\hline groups of entrepreneurs in a region & & .794 & & & \\
\hline group of entrepreneurs in a municipality & & .588 & & & \\
\hline agricultural market agency in other regions & & .558 & & & .466 \\
\hline $\begin{array}{l}\text { local development institutions in neighbouring } \\
\text { municipalities }\end{array}$ & & & .866 & & \\
\hline local development institutions in a region & & & .772 & & \\
\hline local development institutions in a municipality & & & .767 & & \\
\hline $\begin{array}{l}\text { economic self-government in neighbouring } \\
\text { municipalities }\end{array}$ & & & & .801 & \\
\hline economic self-government in a municipality & & & & .787 & \\
\hline economic self-government in a region & & & & .701 & \\
\hline regional service centre for investors & & & & & .849 \\
\hline agricultural market agency in a region & & .460 & & & .514 \\
\hline Percentage of variance & 15.80 & 15.65 & 13.98 & 13.61 & 8.23 \\
\hline
\end{tabular}

Source: the authors' own elaboration based on data from surveys.

Table 2. Participation of types of municipalities in dimensions of institutional networks (\%)

\begin{tabular}{|c|c|c|c|c|c|}
\hline & \multicolumn{5}{|c|}{ High level of dimensions of institutional networks } \\
\cline { 2 - 6 } Type of municipalities & $\begin{array}{c}\text { innovators } \\
\mathbf{n = 1 0 1}\end{array}$ & $\begin{array}{c}\text { entrepreneurs } \\
\mathbf{n = 8 7}\end{array}$ & $\begin{array}{c}\text { local development } \\
\text { agencies } \\
\mathbf{n = 8 0}\end{array}$ & $\begin{array}{c}\text { economic self- } \\
\text { government } \\
\mathbf{n = 7 1}\end{array}$ & $\begin{array}{c}\text { regional } \\
\text { development } \\
\text { agencies } \\
\mathbf{n = 1 0 9}\end{array}$ \\
\hline cities $(\mathrm{n}=\mathbf{7 9 = 1 0 0 \% )}$ & $\mathbf{4 8 . 1}$ & 20.3 & 10.1 & 21.5 & 32.9 \\
\hline Urban-rural $(\mathrm{n}=131=100 \%)$ & 19.8 & 10.7 & 13.0 & 14.5 & 25.2 \\
\hline rural $(\mathrm{n}=318=100 \%)$ & 11.6 & 17.9 & 17.3 & 11.0 & 15.7 \\
\hline
\end{tabular}

Source: the authors' own elaboration.

dimension (Table 2). In other types of municipalities (urbanrural and rural) this percentage is considerably lower (approx. $20 \%$ and $12 \%$ respectively). Of particularly interest is the case of rural communes, who characterize the above institutional dimension as being important for their development. Some of these municipalities are located near large and medium-sized cities, but there are also communes that have a peripheral location in relation to development centres. This result may be related to the activity and importance of secondary schools and special economic zones (SEZ), which, rather surprisingly, belong to this group of institutional networks. Initially, it may have been expected that special economic zones would belong to one of the dimensions strictly related to entrepreneurs; however, it seems that due to the presence of numerous large and international corporations in SMEs, and the relationship of the zones with the activities of governmental and regional agencies, their presence - particularly in peripheral areas, but not only - is perceived as being important for the development of municipalities and is associated with technological progress. Obviously, this does not always reflect the actual impact of the zones on local development (Ambroziak 2014).

The second dimension of significance is created by entrepreneurs and - what is important - by regional development agencies situated in regions other than the studied municipalities. It is worth underlining that in this dimension, groups of entrepreneurs from neighbouring municipalities and from the region in which a given municipality is located, are most important. The explanation for these two facts could be that in the group studied there are numerous rural municipalities (almost 18\%) that must base their economic relations on cooperation with their surroundings (e.g. residents of a given unit go to work in neighbouring municipalities). This "dependence" on external factors may also determine the assessment of regional development agencies operating in other regions. Therefore, the dimension most discussed is represented in rural municipalities frequently located near cities (Figure 2); however, this is obviously 


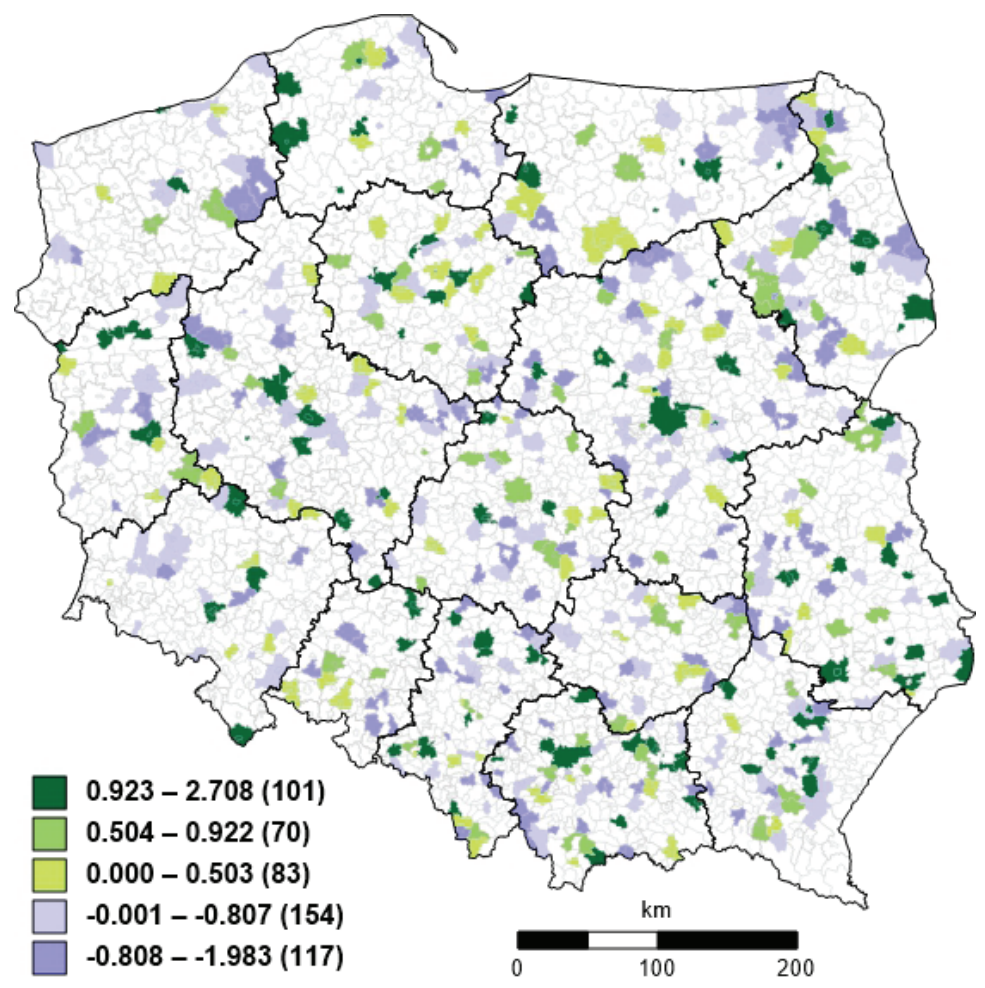

Figure 1. Factor loadings of the dimension - innovators Source: the authors' own elaboration.

not always the case (see Warsaw and Łódź as examples of big cities).

In the third dimension in which local development institutions are included, we also deal with the key role of external institutions in relation to a given municipality, however, other types of institutions are also significantly represented. The significance of local development institutions is mostly reflected in municipalities situated near the main cities and frequently in peripheral municipalities (situated far from voivodeship cities - Figure 3). In this case, when comparing the three types of municipality, the rural municipality is the most common one in this group (about 17\%), while in the cities it is only $10 \%$ and in urban-rural communities, $13 \%$.

In the fourth dimension - economic self-government - we can see only economic self-government institutions of similar significance, however, here also, the first position is taken by an economic self-government in a neighbouring municipality. The spatial distribution of factor loadings suggests that the municipality size translates directly into the significance of economic selfgovernment in a given unit (Figure 4). Economic self-government can be formed in municipalities with the right economic potential, therefore, every fifth urban municipality demonstrates a high level of this network dimension, while in rural municipalities only $11 \%$ do.

The last dimension is called "regional development agencies". Here, two results require highlighting. The first one is the clear predominance of the significance of regional investor assistance centres (IAC) over the remaining two types of institutions. It should be underlined that IACs most frequently belong to the structures of regional development agencies; therefore, it is interesting that the relationships that concern attracting investors are so strongly highlighted by local governments. Another important result is the affiliation of regional development agencies (regional and also in other regions) to more than one dimension. This means that these institutions can play an important role in the institutional networking of various types of entities at the local level. Not only can their location predestine them for such a role (in voivodeship capitals - Figure 5), but also the tasks imposed on them (i.e. building a cooperation network, promoting a given region). In the case of such networks, they are most often seen in urban gminas $^{4}$ (almost $33 \%$ ) while only $15.7 \%$ of rural communes are characterized by this dimension of cooperation. It should be emphasized that networks based on regional institutions are largely visible in urban-rural municipalities $(25.2 \%)$, which is the highest result for this group of municipalities across all types of institutional networks.

Correlations between the determined dimensions of institutional networks and the social and economic characteristics of municipalities, as well as the manner in which local authorities respond questions, allowed several conclusions to be formulated (Table 3).

It is important to emphasize the strong and statistically significant correlation between innovation networks and the population. There is a positive, though weaker, correlation between the size of the municipality and the networks of institutions of economic self-government as well as regional development agencies. There is a positive assessment for the importance of local development agencies and a negative assessment of the importance of regional development agencies in the rural communities that surround the cities and in which the population is growing (as a result of suburbanisation). The latter can be perceived as institutions focused on the entire region, dominating weaker local agencies. Local development agencies also have a positive meaning in municipalities that have, in recent years, attracted new entrepreneurs and in which new workplaces have been created.

${ }^{4} \mathrm{An}$ urban local unit with its own government or cities. 


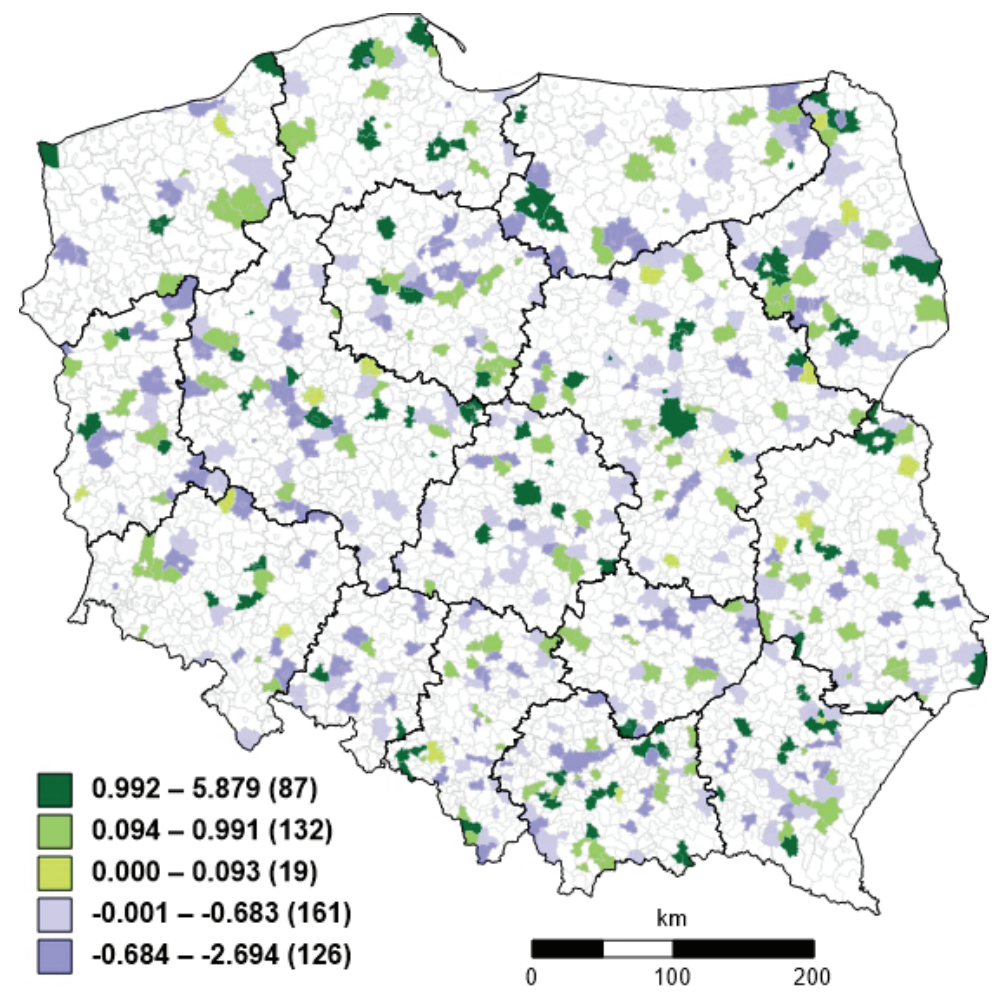

Figure 2. Factor loadings of the dimension - entrepreneurs Source: the authors' own elaboration.

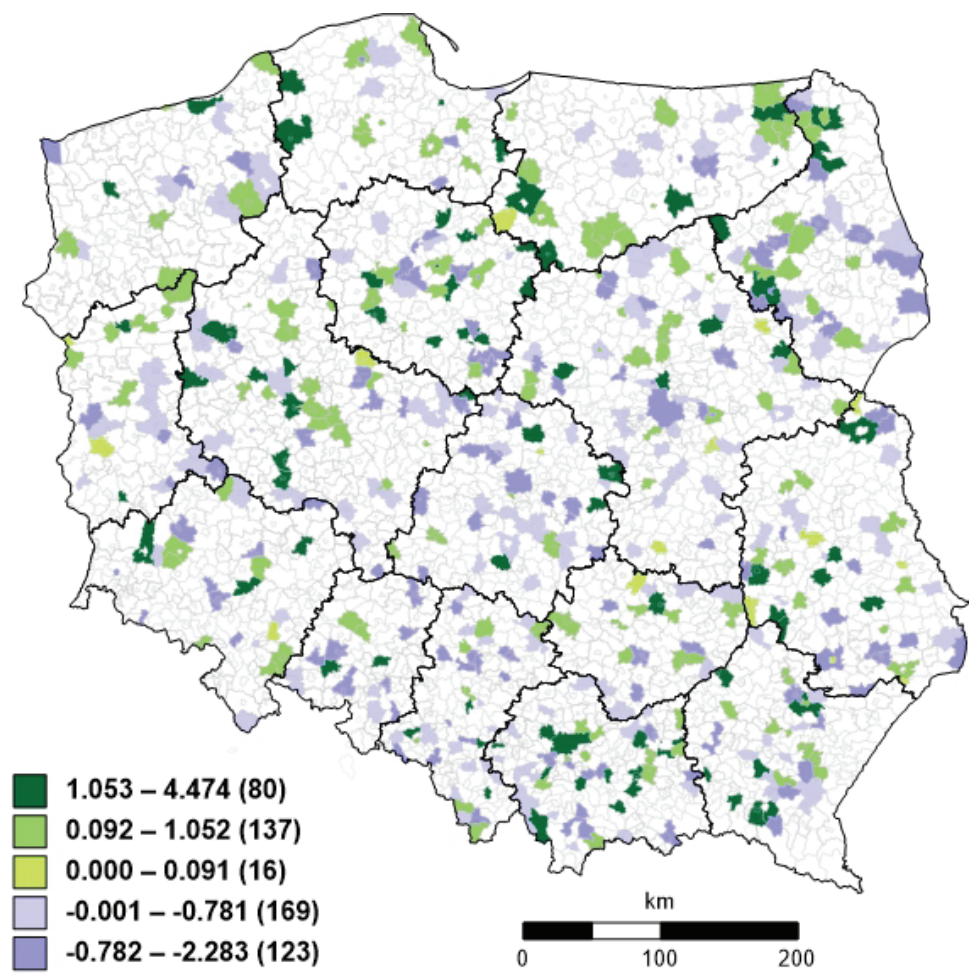

Figure 3. Factor loadings of the dimension - local development agencies Source: the authors' own elaboration. 


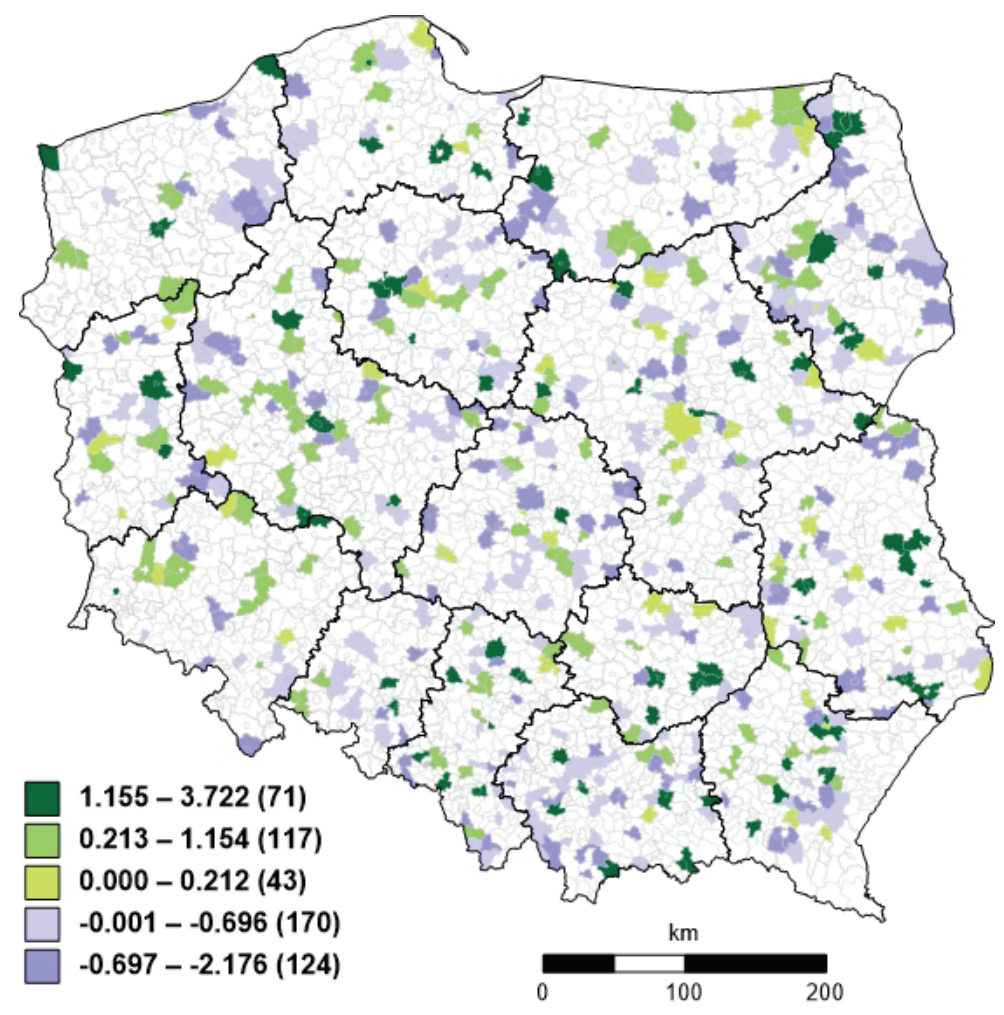

Figure 4. Factor loadings of the dimension - economic self-government Source: the authors' own elaboration.

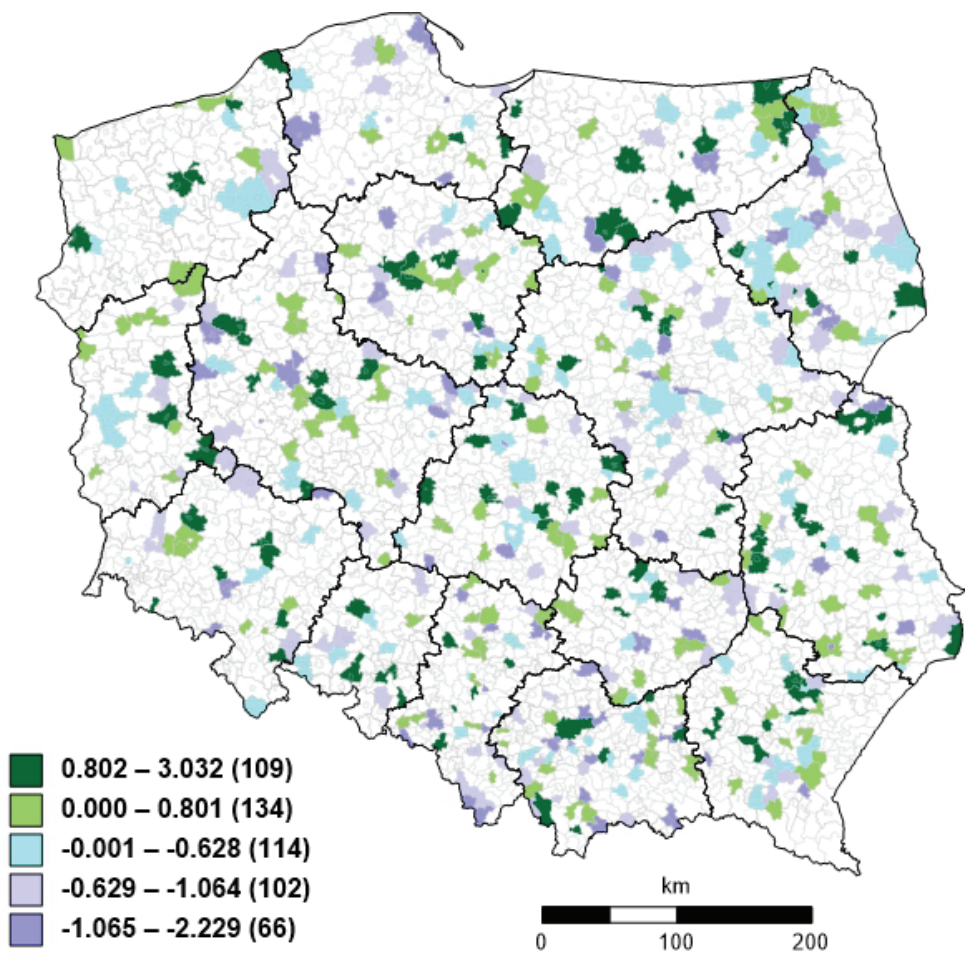

Figure 5. Factor loadings of the dimension - regional development agencies Source: the authors' own elaboration. 
MISCELLANEA GEOGRAPHICA - REGIONAL STUDIES ON DEVELOPMENT

Vol. $21 \cdot$ No. $2 \cdot 2017 \cdot$ pp. 60-67 • ISSN: 2084-6118 • DOI: 10.1515/mgrsd-2017-0024

Table 3. Dimensions of institutional networks and social and economic indices (Pearson's correlation coefficient)

\begin{tabular}{|c|c|c|c|c|c|}
\hline \multirow[b]{2}{*}{ Characteristics of municipalities } & \multicolumn{5}{|c|}{ Dimensions of institutional networks } \\
\hline & innovators & entrepreneurs & $\begin{array}{c}\text { local } \\
\text { development } \\
\text { agencies }\end{array}$ & $\begin{array}{l}\text { economic } \\
\text { self- } \\
\text { government }\end{array}$ & $\begin{array}{c}\text { regional } \\
\text { development } \\
\text { agencies }\end{array}$ \\
\hline Population 2013 & $0.326^{* *}$ & & & $0.158^{* *}$ & $0.141^{* *}$ \\
\hline $\begin{array}{l}\text { Population change } 2010-2013 \text { per } 1,000 \\
\text { residents }\end{array}$ & & & $0.169^{* *}$ & & $-0.088^{*}$ \\
\hline \multicolumn{6}{|l|}{ Income of municipalities 2013 per capita } \\
\hline \multicolumn{6}{|l|}{$\begin{array}{l}\text { Change in the income of municipalities 2010- } \\
2013 \text { per capita }\end{array}$} \\
\hline $\begin{array}{l}\text { Change in the number of people running business } \\
\text { activities } 2010-2013 \text { per } 1,000 \text { residents }\end{array}$ & & & $0.095^{*}$ & & $-0.098^{*}$ \\
\hline $\begin{array}{l}\text { Change in the number of people working } 2010- \\
2013 \text { per } 1,000 \text { residents }\end{array}$ & & & $0.114^{* *}$ & & \\
\hline $\begin{array}{c}\text { Change in the number of non-government } \\
\text { organizations } 2010-2013 \text { per } 1,000 \text { residents }\end{array}$ & $0.099^{*}$ & & & & \\
\hline $\begin{array}{l}\text { "We encourage investors who would like to } \\
\text { cooperate with universities and secondary schools" }\end{array}$ & $0.137^{* *}$ & & & & \\
\hline $\begin{array}{l}\text { "Innovation development as a development } \\
\text { priority of a municipality" }\end{array}$ & $0.195^{\star *}$ & & & & \\
\hline
\end{tabular}

$\left(^{*}\right)$ - statistically significant result with a value of $<0.1\left(^{* *}\right)$ - statistically significant result with a value of $>0.1$

Source: the authors' own elaboration based on data from surveys.

The coexistence of a positive assessment of the institution of innovators, as well as the opinion on the role of innovation, the attitude of local authorities towards universities and secondary schools, and the increase in the number of non-government organizations, are also interesting. The first two dependencies are rather obvious - the local authorities of centres where universities are, and where the network of secondary schools is well-developed, may expect that these elements of the innovation system will be used by potential investors. Such units also have a predisposition to treat innovation development as a strategic priority for a given municipality. The appearance of nongovernment organizations in this comparison does not directly confirm the significance of the fourth element of the quadruple helix (society), but it indirectly indicates the possibility for treating these types of organizations as a component that completes local innovation systems, at least in the context of social innovations. Non-government organizations constitute one of the main entities that create such innovations. It is worth highlighting that the occurrence of various types of innovations in a given space is co-dependent, and simultaneously, changes taking place in the social zone will impact changes in the economy within a certain time perspective (Olejniczuk-Merta 2013).

\section{Conclusions}

This article leads to the conclusion that in numerous municipalities in Poland various institutions operate and play an important role in local development. Since some institutions that are important for the development of municipalities are located outside the borders of such municipalities (sometimes in another administrative region), a key challenge to building local innovation systems is to activate and strengthen processes "outside the borders" of cities and municipalities. Deficiencies in this area were visible when the strategy within the Integrated Territorial Investments was created; they are also manifested in numerous local strategies. Particularly in economically and institutionally weak municipalities, the facilities in neighbouring centres may constitute a basis for being included in the development process determined by innovation and cooperation networks. Referring to the described results, it can be said that the concept of local innovation systems seems to be very attractive to many municipalities outside the main development centres.

\section{Acknowledgements}

The research leading to this paper has received funding from the National Science Centre, Poland under two grants: "Development factors affecting Polish communes in the context of the economic crisis and the new challenges of the European Union" (grant n ${ }^{\circ}$ 2013/09/B/HS5/00164) and "Changing innovation processes models: A chance to break out of path dependency for less developed regions" (grant $n^{\circ}$ DEC-2014/13/B/HS5/03612). These grants were awarded to the University of Warsaw, Faculty of Geography and Regional Studies.

\section{References}

Ambroziak, AA 2014, 'The Legal Framework for Regional State Aid in the European Union in 2014-2020 and Its Impact on the Attractiveness of Poland's Regions to Investors', in New Cohesion Policy of the European Union in Poland. How It Will Influence the Investment Attractiveness of Regions in 2014-2020, ed. AA Ambroziak, Springer, Cham Heidelberg New York Dordrecht London, pp. 63-76.
Asheim, B 2007, 'Differentiated knowledge bases and varieties of regional innovation systems', Innovation, vol. 20, no. 3, pp. 223-241, DOI: 10.1080/13511610701722846.

Asheim, BT \& Isaksen, A 2002, 'Regional Innovation Systems: The Integration of Local 'Sticky' and Global 'Ubiquitous' Knowledge', Journal of Technology Transfer, vol. 27, pp. 77-86. 
Asheim, BT, Smith, HL \& Oughton, C 2011, 'Regional Innovation Systems: Theory, Empirics and Policy', Regional Studies, vol. 45.7, pp. 875-891, DOI: 10.1080/00343404.2011.596701.

Brunow, S \& Miersch, V 2015,'Innovatin capacity, workforce diversity and intra-industrial externalities: a study of German establishments', in The Rise of the City. Spatial Dynamics in the Urban Century, eds K Kourtit, P Nijkamp \& RR Stough, Edward Elgar, Cheltenham, pp. 188-224.

Camagni, RP 1995, 'The concept of innovative milieu and its relevance for public policies in European lagging regions', Papers in regional science, vol. 74(4), pp. 317-340.

Capello, R 1999, 'Spatial Transfer of Knowledge in hightechnology milieu: learning vs. collective learning processes', Regional Studies, vol. 33(4), pp. 353-365.

Capello, R 2012, 'The knowledge economy in European regions: a strategic goal for competitiveness', in Networks, Space and Competitiveness. Evolving Challenges for Sustainable Growth, eds R Capello \& TP Dentinho, Edward Elgar, Cheltenham, pp. 77-106.

Carrincazeaux, C \& Gaschet, F 2015, 'Regional Innovation Systems and Economic Performance: Between Regions and Nations', European Planning Studies, vol. 23, no. 2, pp. 262-291, DOI: 10.1080/09654313.2013.861809.

Charles, DR, Nauwelaers, C, Mouton, B \& Bradley, D 2000, Assessment of the Regional Innovation and Technology Transfer Strategies and Infrastructures (RITTS) Scheme. Final Evaluation Report, CURDS \& MERIT, Newcastle.

Dąbrowska, A 2015, Aktywność uczelni województwa mazowieckiego w kontekście procesu transferu wiedzy. Rozprawa doktorska, Wydział Geografii i Studiów Regionalnych, UW.

Dicken, P 2007, Global Shift. Mapping the Changing Contours of the World Economy, SAGE Publications, Los AngelesLondon-New Delhi.

Diez, JR 2000, 'The Importance of Public Research Institutes in Innovative Networks - Empirical Results from the Metropolitan Innovations Systems Barcelona, Stockholm and Vienna', European Planning Studies, vol. 8, no. 4, pp. 451-463.

Dziemianowicz, W \& Peszat, K 2014, 'Smart specialisations of voivodeships - the first steps toward improvement?', Miscellanea Geographica Regional Studies on Development, vol. 18, no. 1, pp. 37-43.

Fischer, MM 2001, 'Innovation, knowledge creation and systems of innovation', The Annals of Regional Science, vol. 35, pp. 199-216.

Florida, R 1995, 'Toward the Learning Region', Futures, vol. 27, no 5 , pp. 527-536

Florida, R 2002, The Rise of The Creative Class. And How It's Transforming Work, Leisure, Community and Everyday Life, Basic Books, New York.

Foray, D 2015, Smart Specialization. Opportunities and Challenges for Regional Innovation Policy, Routledge, London and New York.

Foss, L \& Gibson, DV 2015, 'The entrepreneurial university. Context and institutional change', in The Entrepreneurial University. Context and institutional change, eds L Foss \& DV Gibson, Routledge, London and New York, pp. 1-17.

Frenkel, A \& Maital, A 2014, Mapping National Innovation Ecosystems. Foundations form Policy Consensus, Edward Edgar, Cheltenham, Northampton.
Geenhuizen, M \& Ye Q 2015, 'Cities as seedbeds of responsible innovation', in The Rise of the City. Spatial Dynamics in the Urban Century, eds K Kourtit, P Nijkamp \& RR Stough, Edward Elgar, Cheltenham, pp. 160-187.

Hägerstrand, T 1967, Innovation Diffusion as a Spatial Process, translation: A. Pred \& G. Haag, University of Chicago Press, Chicago (org. 1953).

Komisja Europejska, 2003, The role of the universities in the Europe of knowledge, komunikat Komisji Europejskiej z dnia 5.02.2003, Bruksela.

Leydesdorff, L 2012, 'The Triple Helix, Quadruple Helix, ..., and an N-Tuple of Helices: Ex-planatory Models for Analyzing the Knowledge-Based Economy?', Journal of the Knowledge Economy, vol. 3, issue 1, pp. 25-35.

Mayer, H, Sager, F, Kaufmann, D \& Warland M 2016, 'Capital city dynamics: Linking regional innovation systems, locational policies and policy regimes', Cities, vol. 51, pp. 11-20.

Moodysson, J \& Zukauskaite, E 2014, 'Institutional Conditions and Innovation Systems: On the Impact of Regional Policy on Firms in Different Sectors', Regional Studies, vol. 48, no. 1, pp. 127-138, DOI: 10.1080/00343404.2011.649004.

Moulaert, F \& Sekia, F 2003, 'Territorial Innovation Models: A Critical Survey', Regional Studies, vol. 37, no. 3, pp. 289302.

OECD, 2009, Investing for Growth: Building Innovative Regions, Policy Report, Paris, 31 March.

Olejniczuk-Merta, A 2013, 'Innowacje społeczne', Konsumpcja i Rozwój, no 1/2013, pp.21-34.

Perry, M 2010, Controversies in Local Economic Development. Stories, strategies, solutions, Routledge, London and New York

Porter, ME 1990, The Competitive Advantage of Nations, The Free Press, New York.

Porter, ME 1998, Competitive Advantage. Creating and Sustaining Superior Performance, The Free Press, New York.

Pylak, K 2015, 'Changing innovation process models: a chance to break out of path dependency for less developed regions', Regional Studies, Regional Science, vol. 2, no. 1, pp. 46-72, DOI: 10.1080/21681376.2014.979433.

Sikora, J \&Uziębło, A 2013, 'Innowacja w przedsiębiorstwie próba zdefiniowania', Zarządzanie i Finanse, vol. 2, no 2, pp. 351-376.

Tödtling, F \& Kaufmann, A 1999, 'Innovation Systems in Regions of Europe - Comparative Perspective', European Planning Studies, vol. 7, no 6, pp. 699-717.

Tödtling, F \& Trippl, M 2011, 'Regional innovation systems', in Handbook of Regional Innovation and Growth, eds P Cooke, B Asheim, R Boschma, R Martin, D Schwartz \& F Tödtling, Edward Edgar, Cheltenham, Northampton, pp. 455-466.

Wojnicka-Sycz, E \& Sycz, P 2016, 'Public Innovation Policy and Other Determinants of Innovativeness in Poland', The Innovation Journal: The Public Sector Innovation Journal, vol. 21 , issue 3 , pp. $1-23$.

Zaucha, J, Brodzicki, T, Ciołek, D, Komornicki, T, Mogiła, Z, Szlachta, J \& Zaleski, J 2015, Terytorialny wymiar wzrostu i rozwoju, Difin, Warszawa. 